Article

\title{
Factors Affecting the Perception and Practice of Iranian Nomadic and Semi-Nomadic Pastoralists in Regard to Biosecurity Practices in Sheep and Goat Farms: A Cross-Sectional and Prospective Study
}

\author{
Zeinab Hatami ${ }^{1,2}$, Richard A. Laven ${ }^{3}{ }^{D}$, Saeid Jafari-Gh. ${ }^{1,2}$, Mahdi Moazez-Lesko ${ }^{1,4} \mathbb{D}$, Pegah Soleimani ${ }^{1,2}$, \\ Ali Jafari-Gh. ${ }^{1,2, *}$, Nima Eila ${ }^{1}$, Jafar Yadi ${ }^{5}$ and Masood Sinafar ${ }^{1}$
}

check for updates

Citation: Hatami, Z.; Laven, R.A.; Jafari-Gh., S.; Moazez-Lesko, M.; Soleimani, P.; Jafari-Gh., A.; Eila, N.; Yadi, J.; Sinafar, M. Factors Affecting the Perception and Practice of Iranian Nomadic and Semi-Nomadic Pastoralists in Regard to Biosecurity Practices in Sheep and Goat Farms: A Cross-Sectional and Prospective Study. Ruminants 2022, 2, 54-73. https://doi.org/10.3390/ ruminants2010003

Academic Editor: Brian J. Leury

Received: 26 August 2021

Accepted: 7 December 2021

Published: 6 January 2022

Publisher's Note: MDPI stays neutral with regard to jurisdictional claims in published maps and institutional affiliations.

Copyright: (C) 2022 by the authors. Licensee MDPI, Basel, Switzerland. This article is an open access article distributed under the terms and conditions of the Creative Commons Attribution (CC BY) license (https:// creativecommons.org/licenses/by/ $4.0 /)$.
1 Faculty of Agriculture and Natural Resources, Department of Animal Science, Islamic Azad University, Karaj Branch, Karaj 3149968111, Iran; monahatami_85@yahoo.com (Z.H.); drsjafari@gmail.com (S.J.-G.); mlmahdi38@yahoo.com (M.M.-L.); pegah_soleimani@ymail.com (P.S.); nima.eila@gmail.com (N.E.); msinafar@ut.ac.ir (M.S.)

2 Saya Sepand Jahan Nama, WESTA Open Innovation Centre, The Agricultural and Natural Resources Science and Technology Park, Karaj 3177777411, Iran

3 School of Veterinary Science, Massey University, Palmerston North 4474, New Zealand; r.laven@massey.ac.nz

4 Animal Science Association, Faculty of Agriculture and Natural Resources, Islamic Azad University, Karaj Branch, Karaj 3149968111, Iran

5 Faculty of Veterinary Science, Islamic Azad University, Saveh Branch, Saveh 3919715179, Iran; amiryadi@yahoo.com

* Correspondence: ali.jafari.gh@ut.ac.ir; Tel.: +98-9108431121

\begin{abstract}
Preventing the spread of diseases between and within farms (biosecurity) is essential for minimizing animal mortality and morbidity, as well as for reducing the risk of spread of zoonotic diseases. These effects are even greater in countries such as Iran, which have to deal with multiple ongoing epidemics of infectious disease. However, there is currently no published information about biosecurity practices on sheep and goat farms in Iran in published research. The aim of this study was to collect such information and to identify some of the factors affecting biosecurity practices. Data were gathered using a checklist and in-depth interviews with 99 nomadic and seminomadic pastoralists. Regression analysis was used to identify the relationships between the collected variables and the biosecurity scores. The results showed that neither within- nor between-farm disease prevention measures were appropriately applied on most farms (median total score of total biosecurity was 37.3/90; Q1 = 29.0 and Q3 = 44.7). Almost all the farmers reported slaughtering animals on farms and nobody properly disposed of the bodies of the dead animals. Additionally, the majority of the participants did not disinfect the umbilical cords of newborns. Of the collected variables, the annual mortality rate was associated with most within-farm biosecurity practices. The increase in annual mortality rates was associated with the regular cleaning of troughs $(p=0.03)$, preventing feed and water from being contaminated by urine and feces $(p=0.02)$, providing a clean and dry place for animals to rest $(p=0.05)$ and disinfecting the navel cord $(p=0.03)$. The results of this survey suggest that there is a clear need for extension programs to enhance Iranian and sheep and goat farmers' perceptions and practices regarding biosecurity measures.
\end{abstract}

Keywords: small ruminants; animal health; preventive measures; disease prevention; animal welfare

\section{Introduction}

Infectious diseases cause significant mortality and economic losses on sheep and goat holdings throughout the world [1]. This is particularly true in Iran, which features 70 million small ruminants, and where important infectious and transboundary diseases, such as foot and mouth disease (FMD), small ruminant pox, and peste des petits ruminants 
(PPR), continue to be prevalent [2-4]. Limiting or preventing the spread of these diseases between and within farms (i.e., optimizing biosecurity) [5] is thus crucial for the welfare and productivity of sheep and goats in Iran and, because of their transboundary nature, the wider west Asian region.

Such control will require the development and implementation of robust biosecurity protocols. However, the majority of sheep and goat holdings in Iran are small-scale holdings (average farm size of $<40$ head) [6], which are mostly managed by illiterate farmers [7-10], with limited education in disease control and management $[8,11]$. This lack of education, combined with small farm sizes [12,13], the type of farm [14], and limited access to veterinary services mean that it is unlikely that biosecurity implementation is currently anywhere near optimal on most Iranian sheep and goat farms. There is thus a clear need for the development of systematic educational programs on a national level to improve the implementation of control measures and preventive protocols on Iranian sheep and goat farms. The development of such programs requires a clear overview of current practices on these farms and an understanding of the factors influencing those practices. However, there are very few data in regard to current biosecurity practices on Iranian sheep and goat farms, which are divided into two main types: nomadic (migrating from lowland to highland depending on seasons) and semi-nomadic (based in a village but using communal grazing lands) $[7,15]$. The goal of this study was therefore to determine the level of knowledge and the practices of nomadic and semi-nomadic pastoralists related to biosecurity practices in Alborz and Qazvin provinces, Iran.

\section{Materials and Methods}

This cross-sectional study was carried out as a part of a bigger survey [11]. The first part of the study aimed to assess the knowledge, attitude and practice of nomadic and semi-nomadic pastoralists in the Alborz and Qazvin provinces of northern Iran in regard to infectious and transboundary diseases, and the second part (in the current report) was intended to assess the perception and practice of the same population in regard to biosecurity.

Farms were selected using a snowball sampling process [16]. Initially, in June 2017, 11 pastoralists known to the authors were approached ( 7 were semi-nomadic and 4 were nomadic) and asked if they would participate in the study. These pastoralists were then asked to recommend further contacts (second wave) who were then contacted and asked to participate. These participants were then asked to recommend further potential interviewees (third wave). We eventually reached a point where we could not find new interviewees. This was mostly because either we had already interviewed the farmer who was being introduced to us, or the interviewer was reluctant to introduce us to his colleagues, or the introduced farmers could not be reached (due to being based in the highlands). To be eligible for participation, the pastoralists needed to own at least six adult sheep and/or goats.

The main reasons why farmers identified as potential participants were not included were: inability to access the farmer for interview due to them being based in the highlands (which applied specifically to nomads); owning no animals at the time of interview or planning to sell their whole herd due to economic issues; lack of trust in the research team; and lack of time to participate in this part of the study $(n=14)$.

The location of each interview (e.g., on shared pasture, on private farm, or at home) was determined by the participant. Informed consent was obtained verbally at the beginning of each interview. The interviewees were assured that their name and personal information were confidential and would not be shared with any governmental organization (e.g., insurance companies, the Iranian Vet Organization). They were also assured that they were free to withdraw from the interviews at any time. Some farmers did leave the study during the interviews (Figure 1). 


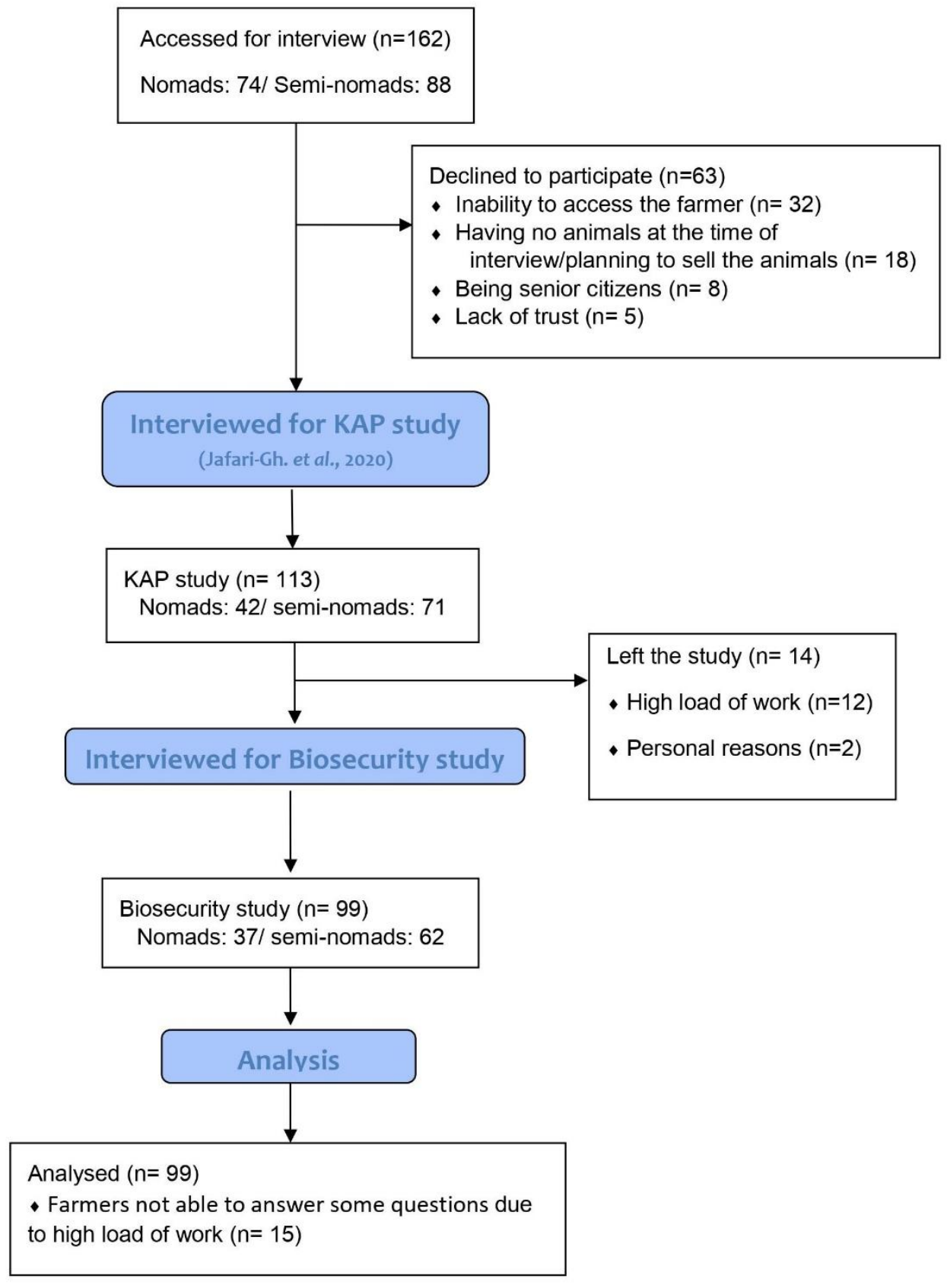

Figure 1. Number of farmers who were approached for interview, and the reasons for declining to participate or leaving the study.

The final questionnaire consisted of a demographic section, and 43 open-ended questions and observation checklists, of which 19 were related to biosecurity (Table 1). For the observation checklist, in situations where making observations was not possible, e.g., the participant was being interviewed away from where they kept their animals, the participants were asked to answer a related question. For example, for "avoid water and feed being contaminated by urine and feces", we expected to observe some kind of barrier (such as a horizontal bar) installed above the troughs. Where it was not possible to make such observations, the participant was asked if they have installed such barriers, and a score was given based on the farmer's answer. The correct answer was given the score presented in Table 1, and wrong answers received a score of zero. 
Table 1. Observations form assessing sheep and goat farmers' perception and practice regarding biosecurity practices and the scoring protocol of the questions. Practices are categorized into "within-farm measures", "between-farm measures" and "measures related to veterinary practices" for better understanding.

\begin{tabular}{|c|c|c|}
\hline Category & Sub-Categories & Score \\
\hline \multicolumn{3}{|c|}{ Within-Farm Biosecurity Measures } \\
\hline \multirow{5}{*}{ Using washable material in the barn ${ }^{1}$} & Floor & 1 \\
\hline & Walls & 1 \\
\hline & Ceiling & 1 \\
\hline & Water trough & 1 \\
\hline & Feed trough & 1 \\
\hline \multirow{2}{*}{ Cleansing the feed and water troughs everyday } & Feed trough & 2.5 \\
\hline & Water trough & 2.5 \\
\hline \multirow{2}{*}{ Avoiding water and feed to be infected by feces and urine } & Feed trough & 2.5 \\
\hline & Water trough & 2.5 \\
\hline \multirow{2}{*}{ Providing a clean and dry place for the animals to rest } & Cleaning the stall & 2.5 \\
\hline & Barnyard & 2.5 \\
\hline Avoiding placing feed or salt stones on the ground ${ }^{2}$ & $\mathrm{~N} / \mathrm{A}$ & 5 \\
\hline Isolating sick animals (until animal shows no clinical signs) & $\mathrm{N} / \mathrm{A}$ & 5 \\
\hline Disinfecting the umbilical cord of newborns (until it dries off) & $\mathrm{N} / \mathrm{A}$ & 5 \\
\hline Avoiding slaughtering animals on the farm & $\mathrm{N} / \mathrm{A}$ & 5 \\
\hline \multirow{2}{*}{ Health of shepherd dogs } & Feeding healthy food & 2.5 \\
\hline & Vaccinations against rabies & 2.5 \\
\hline \multicolumn{3}{|c|}{ Between-Farm Biosecurity Measures } \\
\hline \multirow{2}{*}{ Preventing rodents and birds from gaining access to feed } & Covered feed storage facilities & 2.5 \\
\hline & Fighting against rodents (poisons or traps) & 2.5 \\
\hline \multirow[t]{2}{*}{ Fighting against external parasites that act as vectors } & $\begin{array}{l}\text { Spraying appropriate products, or using flame } \\
\text { splash }\end{array}$ & 2.5 \\
\hline & Owning sheep dips & 2.5 \\
\hline Quarantining newcomers (for 2 weeks) & $\mathrm{N} / \mathrm{A}$ & 5 \\
\hline \multirow{3}{*}{$\begin{array}{l}\text { Controlling the spread of pathogens through the } \\
\text { appropriate disposal of: }\end{array}$} & Placenta and aborted fetus & 1.75 \\
\hline & Milk & 1.75 \\
\hline & Wool & 1.5 \\
\hline Appropriate disposal of dead animals & Burning or deep burying & 5 \\
\hline Disinfecting the instruments which are routinely used & $\mathrm{N} / \mathrm{A}$ & 5 \\
\hline $\begin{array}{c}\text { Maintaining a } 1 \mathrm{~km} \text { (0.6 mile) distance from sick } \\
\text { surrounding flocks }\end{array}$ & $\mathrm{N} / \mathrm{A}$ & 5 \\
\hline
\end{tabular}

\section{Measures Related to Veterinary Practices}

\begin{tabular}{cll}
\hline Recording the time and type of vaccinations and treatments & N/A & 5 \\
\hline Consulting veterinaries & N/A & 5 \\
\hline Prescribed use of antibiotics and drugs & N/A & 5 \\
\hline $\begin{array}{l}{ }^{1} \text { Cement, plastic, and metal were considered as washable, while wood, mud and bricks were considered non- } \\
\text { washable. }{ }^{2} \text { This category was assessed but was not analyzed due to a lack of collected data (since some interviews } \\
\text { were conducted outside of the farm (e.g., on pasture) and farmers did not provide enough information on } \\
\text { the subject). }\end{array}$ &
\end{tabular}

The data were analyzed using SPSS version 26 (IBM, Seattle, WA, USA). The normality of data was assessed using the Shapiro-Wilk test. Normal data were analyzed using linear regression, while for non-normal data an ordinal logistic regression was used. Collinearity was checked for using Spearman's rank correlation. All the remaining variables were 
included in the final model. The socio-demographic factors that were recorded during the interviews and the way they were categorized in the regression analysis can be seen in Table 2. The results of the model are reported for all the factors where $p<0.1$ in the final model.

Table 2. Recorded socio-demographic factors and their categorization in the regression analysis.

\begin{tabular}{cc}
\hline Factor & Classification in the Regression Analysis * \\
\hline Experience & One year \\
Number of animals & One hundred animals \\
Annual mortality & One percent \\
Literacy & 1 -illiterate; 2 -semi-literate; 3 -literate \\
Farming system & 1 -nomadic; 2 -semi-nomadic \\
Union membership & 0 -non-member; 1 -member \\
\hline *For the continuous variables, this determines the unit of the factor included in the calculation of the $\beta$-coefficient
\end{tabular}

\section{Results}

The snowball sampling process identified 162 pastoralists ( 74 nomads, 88 semi-nomads) of which 113 (42 nomads, 71 semi-nomads) agreed to take part in the survey. Of these 113, 99 (37 nomads, 62 semi-nomads) agreed to take part in this section of the study, yet not all of the 99 participants answered all the questions. Figure 1 illustrates the number of participants initially approached and those whose data were analyzed in the study.

The number of farmers who answered each question can be seen in Table 3. Of the 19 questions included in the questionnaire in relation to biosecurity (Table 3), data were collected for one category (avoid putting feed or salt stones on the ground), but it was omitted from the analysis as not enough data could be collected during visits or interviews.

Table 3. Distribution of biosecurity scores (by question and total) and the percentage of farmers who thoroughly applied the measures (e.g., prevented both water and feed to be contaminated). The maximum score for each category is five.

\begin{tabular}{|c|c|c|c|c|c|c|c|c|}
\hline Variable & Mean & Median & $\begin{array}{l}\text { Standard } \\
\text { Deviation }\end{array}$ & $\begin{array}{c}\text { Lower } \\
\text { Quartile }\end{array}$ & $\begin{array}{c}\text { Upper } \\
\text { Quartile }\end{array}$ & $\begin{array}{c}\text { \% Farmers } \\
\text { Who } \\
\text { Applied } \\
\text { the } \\
\text { Measure }\end{array}$ & $\begin{array}{l}\text { Number } \\
\text { of Re- } \\
\text { spondents }\end{array}$ & $\begin{array}{c}\text { Normal } \\
\text { Distribution }\end{array}$ \\
\hline \multicolumn{9}{|c|}{ Within-Farm Biosecurity Measures } \\
\hline $\begin{array}{l}\text { Using washable } \\
\text { materials in the } \\
\text { barn }\end{array}$ & 3.3 & 4.0 & 1.6 & 2.0 & 4.0 & 24 & 91 & $\mathrm{~N}$ \\
\hline $\begin{array}{l}\text { Cleansing the } \\
\text { feed and water } \\
\text { troughs }\end{array}$ & 3.3 & 5.0 & 2.1 & 2.5 & 5.0 & 55 & 85 & $\mathrm{Y}$ \\
\hline $\begin{array}{l}\text { Preventing water } \\
\text { and feed from } \\
\text { being infected by } \\
\text { feces and urine }\end{array}$ & 2.9 & 2.5 & 2.1 & 0.0 & 5.0 & 44 & 90 & $\mathrm{Y}$ \\
\hline $\begin{array}{c}\text { Providing a clean } \\
\text { and dry place for } \\
\text { the animals to } \\
\text { rest }\end{array}$ & 2.1 & 0.0 & 2.3 & 0.0 & 5.0 & 31 & 88 & $\mathrm{~N}$ \\
\hline $\begin{array}{l}\text { Quarantining } \\
\text { sick animals }\end{array}$ & 2.0 & 0.0 & 2.5 & 0.0 & 5.0 & 40 & 96 & $\mathrm{Y}$ \\
\hline
\end{tabular}


Table 3. Cont.

\begin{tabular}{|c|c|c|c|c|c|c|c|c|}
\hline Variable & Mean & Median & $\begin{array}{l}\text { Standard } \\
\text { Deviation }\end{array}$ & $\begin{array}{c}\text { Lower } \\
\text { Quartile }\end{array}$ & $\begin{array}{c}\text { Upper } \\
\text { Quartile }\end{array}$ & $\begin{array}{c}\% \text { Farmers } \\
\text { Who } \\
\text { Applied } \\
\text { the } \\
\text { Measure }\end{array}$ & $\begin{array}{l}\text { Number } \\
\text { of Re- } \\
\text { spondents }\end{array}$ & $\begin{array}{c}\text { Normal } \\
\text { Distribution } 1\end{array}$ \\
\hline $\begin{array}{l}\text { Disinfecting the } \\
\text { umbilical cord } \\
\text { Avoiding }\end{array}$ & 1.0 & 0.0 & 2.0 & 0.0 & 0.0 & 19 & 98 & $\mathrm{~N}$ \\
\hline $\begin{array}{l}\text { slaughtering } \\
\text { animals on the } \\
\text { farm }\end{array}$ & 0.1 & 0.0 & 0.7 & 0.0 & 0.0 & 2 & 98 & $\mathrm{~N}$ \\
\hline $\begin{array}{c}\text { Health of } \\
\text { shepherd dogs }\end{array}$ & 0.9 & 0.0 & 1.6 & 0.0 & 2.5 & 8 & 96 & $\mathrm{~N}$ \\
\hline \multicolumn{9}{|c|}{ Between-Farm Biosecurity Measures } \\
\hline $\begin{array}{l}\text { Preventing } \\
\text { rodents and birds } \\
\text { from gaining } \\
\text { access to feed }\end{array}$ & 2.9 & 2.5 & 1.9 & 2.5 & 5.0 & 36 & 84 & $\mathrm{Y}$ \\
\hline $\begin{array}{l}\text { Fighting against } \\
\text { external parasites } \\
\text { that act as vectors }\end{array}$ & 2.8 & 2.5 & 1.4 & 2.5 & 2.5 & 23 & 99 & $\mathrm{~N}$ \\
\hline $\begin{array}{l}\text { Quarantining } \\
\text { newcomers }\end{array}$ & 0.7 & 0.0 & 1.8 & 0.0 & 0.0 & 15 & 95 & $\mathrm{~N}$ \\
\hline $\begin{array}{l}\text { Controlling the } \\
\text { spread of } \\
\text { pathogens } \\
\text { through body } \\
\text { secretions and } \\
\text { parts of body }\end{array}$ & 0.6 & 0.0 & 1.1 & 0.0 & 1.5 & 1 & 98 & $\mathrm{~N}$ \\
\hline $\begin{array}{c}\text { Appropriate } \\
\text { disposal of dead } \\
\text { animals }\end{array}$ & 0.3 & 0.0 & 1.2 & 0.0 & 0.0 & 6 & 99 & $\mathrm{~N}$ \\
\hline $\begin{array}{l}\text { Disinfecting } \\
\text { shared } \\
\text { instruments }\end{array}$ & 0.5 & 0.0 & 1.5 & 0.0 & 0.0 & 10 & 96 & $\mathrm{~N}$ \\
\hline $\begin{array}{c}\text { Maintaining a } \\
\text { distance with } \\
\text { surrounding sick } \\
\text { flocks }\end{array}$ & 3.2 & 5.0 & 2.6 & 0.0 & 5.0 & 60 & 97 & $\mathrm{Y}$ \\
\hline \multicolumn{9}{|c|}{ Measures Related to Veterinary Practices } \\
\hline $\begin{array}{l}\text { Prescribed use of } \\
\text { antibiotics and } \\
\text { drug }\end{array}$ & 2.4 & 0.0 & 2.5 & 0.0 & 5.0 & 44 & 97 & $\mathrm{Y}$ \\
\hline $\begin{array}{l}\text { Consulting } \\
\text { veterinaries }\end{array}$ & 2.6 & 5.0 & 2.5 & 0.0 & 5.0 & 49 & 96 & $\mathrm{Y}$ \\
\hline $\begin{array}{l}\text { Recording the } \\
\text { time and type of } \\
\text { vaccinations and } \\
\text { treatments }\end{array}$ & 1.0 & 0.0 & 2.0 & 0.0 & 0.0 & 21 & 96 & $\mathrm{~N}$ \\
\hline $\begin{array}{l}\text { Total biosecurity } \\
\text { score }\end{array}$ & 36.8 & 37.3 & 14.5 & 29.0 & 44.7 & - & 99 & Y \\
\hline
\end{tabular}

${ }^{1} \mathrm{Y}=\mathrm{Yes}, \mathrm{N}=$ No.

\subsection{Demographic Variables}

The median number of animals on each farm was 308 head $(\mathrm{Q} 1=120$ and Q3 = 523); the median annual mortality rate was 5.0\% $(\mathrm{Q} 1=2.2$ and $\mathrm{Q} 3=9.4)$, with a strong 
right-skewed distribution (Figure 2). The median years of experience was 15 (Q1 = 7 and Q3 = 27), with a right-skewed distribution (Figure 3). Of the participants, $34 \%$ were literate, $37 \%$ were nomadic pastoralists and $60 \%$ were not members of any unions.

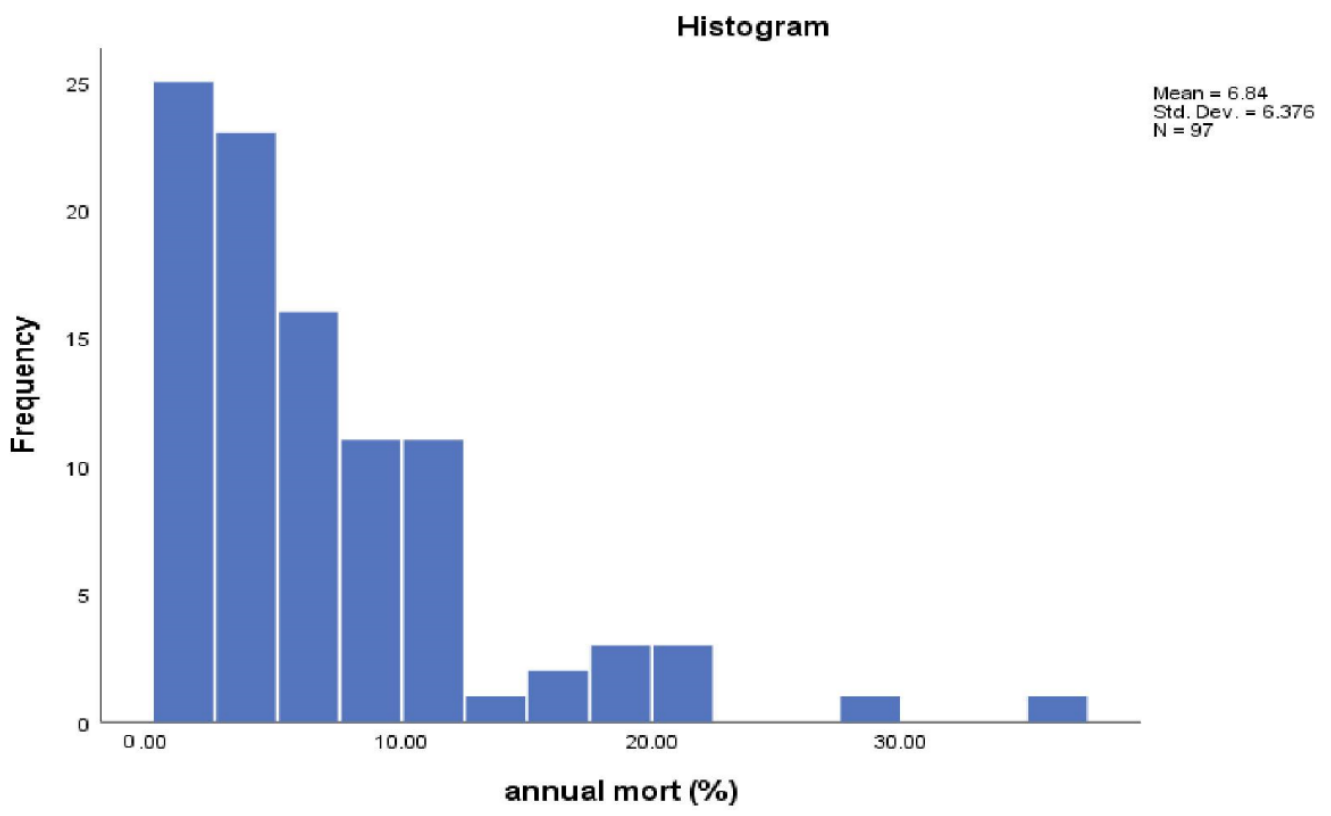

Figure 2. Mean, standard deviation, and distribution of annual mortality percentage.

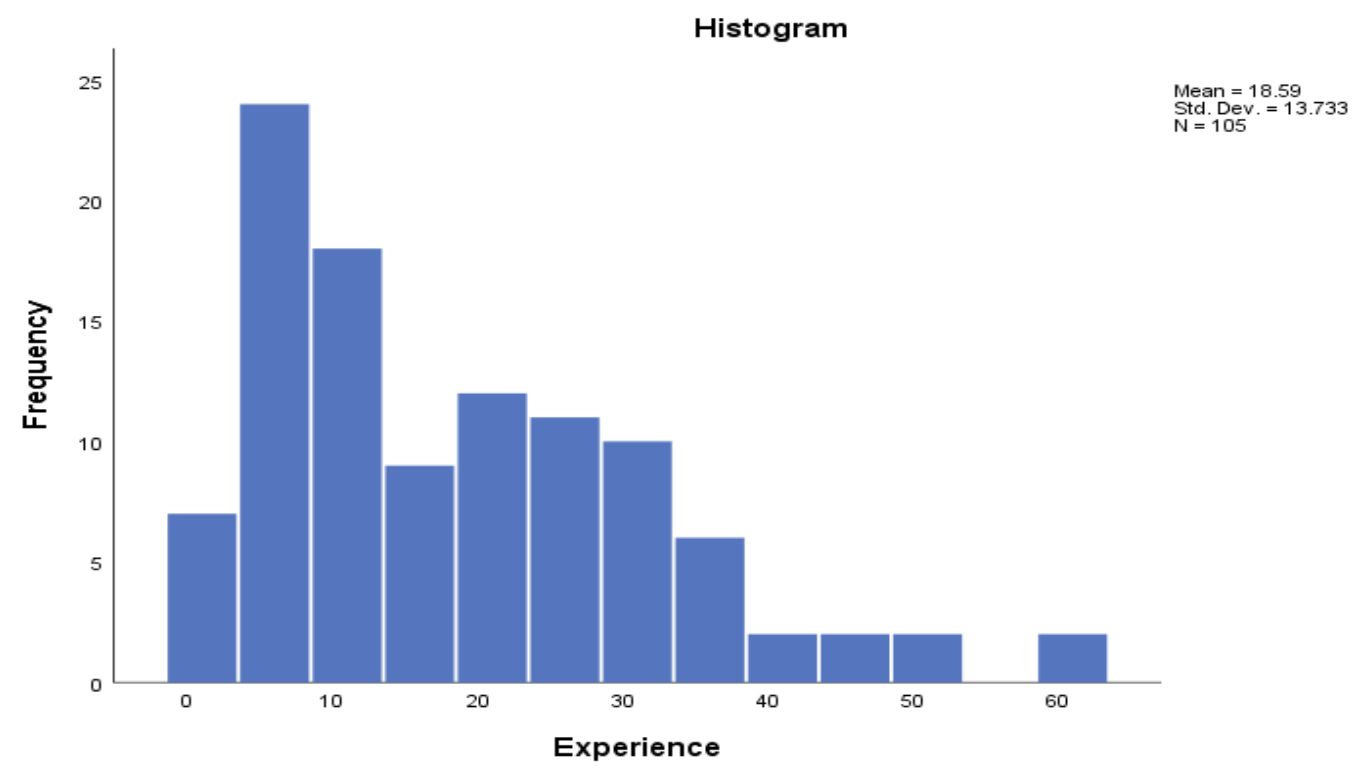

Figure 3. Mean, standard deviation, and distribution of years of experience of participants.

\subsection{Within-Farm Biosecurity Measures}

This category included the washability of materials, cleaning the feed and water troughs, avoiding feed and water contamination, providing a clean place for animals to rest, disinfecting the navel cord, isolating sick animals, maintaining the health of sheep dogs, slaughtering on farm, and controlling the spread of pathogens through body secretions, bodyparts, and dead animals (Tables 4 and 5). 
Table 4. The effects of different demographic parameters on biosecurity measures using ordinal logistic regression analysis (for parameters with non-normal distribution).

\begin{tabular}{ccccc}
\hline Source & F & DF 1 & DF 2 & $p$-Value \\
\hline \multicolumn{4}{c}{ Using Washable Materials in the Barn } \\
\hline Corrected Model & 1.40 & 7 & 393 & 0.20 \\
Annual mortality \% & 3.21 & 1 & 393 & 0.07 \\
Experience & 1.58 & 1 & 393 & 0.21 \\
Literacy & 2.16 & 2 & 393 & 0.12 \\
Farming System & 1.30 & 1 & 393 & 0.25 \\
Union Membership & 0.02 & 1 & 393 & 0.88 \\
Number of Animals & 2.06 & 1 & 393 & 0.15 \\
\hline \multicolumn{1}{c}{ Providing a Clean and Dry Place for the Animals to Rest } & \\
\hline Corrected Model & 1.20 & 7 & 143 & 0.31 \\
Annual mortality \% & 4.06 & 1 & 143 & 0.05 \\
Experience & 2.27 & 1 & 143 & 0.13 \\
Literacy & 1.40 & 2 & 143 & 0.25 \\
Farming System & 0.44 & 1 & 143 & 0.51 \\
Union Membership & 1.38 & 1 & 143 & 0.24 \\
Number of Animals & 0.09 & 1 & & \\
\hline & Quarantining & Newcomers & 74 \\
\hline Corrected Model & 0.97 & 7 & 74 & 0.46 \\
Annual mortality \% & 2.32 & 1 & 74 & 0.13 \\
Experience & 0.05 & 1 & 74 & 0.82 \\
Literacy & 1.71 & 1 & 74 & 0.93 \\
Union Membership & 0.01 & 1 & 74 &
\end{tabular}

Fighting against External Parasites that Act as Vectors

\begin{tabular}{ccccc}
\hline Corrected Model & 1.32 & 8 & 158 & 0.24 \\
Annual mortality \% & 0.37 & 1 & 158 & 0.54 \\
Experience & 2.26 & 1 & 158 & 0.14 \\
Literacy & 0.25 & 2 & 158 & 0.78 \\
Farming System & 2.38 & 1 & 158 & 0.13 \\
Union Membership & 1.75 & 1 & 158 & 0.19 \\
Number of Animals & 1.02 & 1 & 158 & 0.31 \\
\hline & Disinfecting the Umbilical Cord & & 0.21 \\
\hline Corrected Model & 1.43 & 7 & 75 & 0.03 \\
Annual mortality \% & 5.10 & 1 & 75 & 0.10 \\
Experience & 2.76 & 1 & 75 & 0.38 \\
Literacy & 0.99 & 2 & 75 & 0.29 \\
Farming System & 1.15 & 1 & 75 & 0.10 \\
Union Membership & 2.80 & 1 & 75 & 0.46 \\
Number of Animals & 0.56 & 1 & 403 & 0.78 \\
\hline Controlling the Spread of Pathogens through Body Secretions and Parts of Body \\
\hline Corrected Model & 0.58 & 7 & 403 & 0.81 \\
Annual mortality \% & 0.06 & 1 & 403 & 0.58 \\
Experience & 0.31 & 1 & 403 & 0.52 \\
Literacy & 0.66 & 2 & 403 & 0.48 \\
Farming System & 0.51 & 1 & 403 & 0.32 \\
Union Membership & 0.98 & 1 & 403 & 0.63 \\
Number of Animals & 0.24 & \multicolumn{3}{l}{}
\end{tabular}


Table 4. Cont.

\begin{tabular}{|c|c|c|c|c|}
\hline Source & $\mathbf{F}$ & DF 1 & DF 2 & $p$-Value \\
\hline \multicolumn{5}{|c|}{ Appropriate Disposal of Dead Animals } \\
\hline Corrected Model & 0.51 & 7 & 76 & 0.83 \\
\hline Annual mortality \% & 0.48 & 1 & 76 & 0.49 \\
\hline Experience & 1.33 & 1 & 76 & 0.25 \\
\hline Literacy & 0.39 & 2 & 76 & 0.68 \\
\hline Farming System & 1.02 & 1 & 76 & 0.32 \\
\hline Union Membership & 0.00 & 1 & 76 & 0.99 \\
\hline Number of Animals & 0.04 & 1 & 76 & 0.85 \\
\hline \multicolumn{5}{|c|}{ Avoiding Slaughtering Animals on the Farm } \\
\hline Corrected Model & 0.33 & 6 & 75 & 0.92 \\
\hline Annual mortality \% & 0.74 & 1 & 75 & 0.39 \\
\hline Experience & 1.03 & 1 & 75 & 0.31 \\
\hline Literacy & 0.09 & 2 & 75 & 0.92 \\
\hline Farming System & 0.21 & 1 & 75 & 0.65 \\
\hline Union Membership & 0.00 & 1 & 75 & 0.99 \\
\hline Number of Animals & 0.00 & 1 & 75 & 0.99 \\
\hline \multicolumn{5}{|c|}{ Health of Shepherd Dogs } \\
\hline Corrected Model & 0.75 & 7 & 155 & 0.63 \\
\hline Annual mortality \% & 0.02 & 1 & 155 & 0.88 \\
\hline Experience & 3.55 & 1 & 155 & 0.06 \\
\hline Literacy & 0.42 & 2 & 155 & 0.66 \\
\hline Farming System & 0.00 & 1 & 155 & 0.97 \\
\hline Union Membership & 0.53 & 1 & 155 & 0.47 \\
\hline Number of Animals & 1.15 & 1 & 155 & 0.29 \\
\hline \multicolumn{5}{|c|}{ Disinfecting Shared Instruments } \\
\hline Corrected Model & 0.83 & 7 & 73 & 0.57 \\
\hline Annual mortality \% & 0.00 & 1 & 73 & 0.95 \\
\hline Experience & 0.01 & 1 & 73 & 0.91 \\
\hline Literacy & 1.64 & 2 & 73 & 0.20 \\
\hline Farming System & 0.16 & 1 & 73 & 0.69 \\
\hline Union Membership & 2.57 & 1 & 73 & 0.11 \\
\hline Number of Animals & 0.06 & 1 & 73 & 0.81 \\
\hline \multicolumn{5}{|c|}{ Recording the Time and Type of Vaccinations and Treatments } \\
\hline Corrected Model & 0.64 & 7 & 73 & 0.72 \\
\hline Annual mortality \% & 2.09 & 1 & 73 & 0.15 \\
\hline Experience & 0.24 & 1 & 73 & 0.62 \\
\hline Literacy & 0.30 & 2 & 73 & 0.75 \\
\hline Farming System & 0.05 & 1 & 73 & 0.83 \\
\hline Union Membership & 0.47 & 1 & 73 & 0.50 \\
\hline Number of Animals & 0.52 & 1 & 73 & 0.47 \\
\hline
\end{tabular}

Table 5. The effect of demographic variables on some biosecurity measures using linear regression (for normally distributed parameters).

\begin{tabular}{|c|c|c|c|c|c|}
\hline $\begin{array}{l}\text { Demographic } \\
\text { Variables }\end{array}$ & Coefficient & $\begin{array}{l}\text { Standard } \\
\text { Error }\end{array}$ & \multicolumn{2}{|c|}{ 95\% Confidence Interval } & $p$-Value \\
\hline \multicolumn{6}{|c|}{ Preventing Water and Feed from Being Infected by Feces and Urine } \\
\hline Experience & 0.04 & 0.02 & 0.00 & 0.07 & 0.05 \\
\hline Literacy & 0.78 & 0.37 & 0.04 & 1.52 & 0.04 \\
\hline Farming System & 0.03 & 0.49 & -0.95 & 1.01 & 0.95 \\
\hline
\end{tabular}


Table 5. Cont.

\begin{tabular}{|c|c|c|c|c|c|}
\hline $\begin{array}{c}\text { Demographic } \\
\text { Variables }\end{array}$ & Coefficient & $\begin{array}{c}\text { Standard } \\
\text { Error }\end{array}$ & \multicolumn{2}{|c|}{ 95\% Confidence Interval } & \multirow{2}{*}{$\begin{array}{c}p \text {-Value } \\
0.88\end{array}$} \\
\hline $\begin{array}{c}\text { Number of } \\
\text { Animals }\end{array}$ & -0.01 & 0.04 & -0.09 & 0.08 & \\
\hline $\begin{array}{c}\text { Annual Mortality } \\
(\%)\end{array}$ & 0.10 & 0.05 & 0.01 & 0.19 & 0.02 \\
\hline $\begin{array}{c}\text { Union } \\
\text { Membership }\end{array}$ & 0.04 & 0.50 & -0.97 & 1.04 & 0.94 \\
\hline Constant & -0.17 & 1.38 & -2.92 & 2.57 & 0.90 \\
\hline \multicolumn{6}{|c|}{ Preventing Rodents and Birds from Gaining Access to Feed } \\
\hline Experience & 0.02 & 0.02 & -0.02 & 0.05 & 0.34 \\
\hline Literacy & 0.35 & 0.36 & -0.36 & 1.07 & 0.33 \\
\hline Farming System & -0.34 & 0.47 & -1.28 & 0.61 & 0.48 \\
\hline $\begin{array}{c}\text { Number of } \\
\text { Animals }\end{array}$ & 0.02 & 0.04 & -0.05 & 0.10 & 0.53 \\
\hline $\begin{array}{c}\text { Annual Mortality } \\
(\%)\end{array}$ & 0.03 & 0.04 & -0.04 & 0.11 & 0.36 \\
\hline $\begin{array}{c}\text { Union } \\
\text { Membership }\end{array}$ & 0.16 & 0.49 & -0.81 & 1.13 & 0.75 \\
\hline Constant & 1.84 & 1.35 & -0.86 & 4.55 & 0.18 \\
\hline \multicolumn{6}{|c|}{ Cleaning Feed and Water Troughs } \\
\hline Experience & 0.01 & 0.02 & -0.03 & 0.05 & 0.52 \\
\hline Literacy & -0.11 & 0.39 & -0.90 & 0.68 & 0.79 \\
\hline Farming System & 0.48 & 0.52 & -0.55 & 1.52 & 0.35 \\
\hline $\begin{array}{c}\text { Number of } \\
\text { Animals }\end{array}$ & 0.06 & 0.04 & -0.02 & 0.15 & 0.15 \\
\hline $\begin{array}{c}\text { Annual Mortality } \\
(\%)\end{array}$ & 0.09 & 0.04 & 0.01 & 0.17 & 0.03 \\
\hline $\begin{array}{l}\text { Union } \\
\text { Membership }\end{array}$ & -0.63 & 0.54 & -1.71 & 0.44 & 0.24 \\
\hline Constant & 1.88 & 1.46 & -1.05 & 4.81 & 0.20 \\
\hline \multicolumn{6}{|c|}{ Quarantining Sick Animals } \\
\hline Experience & -0.02 & 0.02 & -0.06 & 0.03 & 0.47 \\
\hline Literacy & 0.55 & 0.43 & -0.30 & 1.40 & 0.20 \\
\hline Farming System & -0.20 & 0.59 & -1.38 & 0.98 & 0.74 \\
\hline $\begin{array}{c}\text { Number of } \\
\text { Animals }\end{array}$ & 0.02 & 0.05 & -0.12 & 0.08 & 0.68 \\
\hline $\begin{array}{l}\text { Annual Mortality } \\
\qquad(\%)\end{array}$ & -0.02 & 0.04 & -0.11 & 0.07 & 0.70 \\
\hline $\begin{array}{c}\text { Union } \\
\text { Membership }\end{array}$ & -0.55 & 0.60 & -1.74 & 0.65 & 0.37 \\
\hline Constant & 1.69 & 1.68 & -1.66 & 5.05 & 0.32 \\
\hline \multicolumn{6}{|c|}{ Prescribed Use of Antibiotics and Drugs } \\
\hline Experience & 0.01 & 0.02 & -0.04 & 0.05 & 0.75 \\
\hline Literacy & -0.36 & 0.45 & -1.26 & 0.54 & 0.43 \\
\hline Farming System & -0.24 & 0.61 & -1.46 & 0.99 & 0.70 \\
\hline $\begin{array}{c}\text { Number of } \\
\text { Animals }\end{array}$ & -0.03 & 0.05 & -0.13 & 0.08 & 0.59 \\
\hline $\begin{array}{l}\text { Annual Mortality } \\
\qquad(\%)\end{array}$ & 0.07 & 0.05 & -0.02 & 0.16 & 0.13 \\
\hline $\begin{array}{l}\text { Union } \\
\text { Membership }\end{array}$ & -0.70 & 0.63 & -1.96 & 0.56 & 0.27 \\
\hline Constant & 3.40 & 1.72 & -0.02 & 6.82 & 0.05 \\
\hline
\end{tabular}


Table 5. Cont.

\begin{tabular}{|c|c|c|c|c|c|}
\hline $\begin{array}{l}\text { Demographic } \\
\text { Variables }\end{array}$ & Coefficient & $\begin{array}{l}\text { Standard } \\
\text { Error }\end{array}$ & \multicolumn{2}{|c|}{ 95\% Confidence Interval } & $p$-Value \\
\hline \multicolumn{6}{|c|}{ Consulting a Vet in Case of Disease Outbreaks } \\
\hline Experience & 0.06 & 0.02 & 0.02 & 0.11 & 0.01 \\
\hline Literacy & 0.16 & 0.43 & -0.69 & 1.02 & 0.70 \\
\hline Farming System & 0.43 & 0.57 & -0.70 & 1.57 & 0.45 \\
\hline $\begin{array}{c}\text { Number of } \\
\text { Animals }\end{array}$ & -0.06 & 0.05 & -0.16 & 0.04 & 0.23 \\
\hline $\begin{array}{c}\text { Annual Mortality } \\
(\%)\end{array}$ & 0.00 & 0.04 & -0.09 & 0.09 & 0.98 \\
\hline $\begin{array}{c}\text { Union } \\
\text { Membership }\end{array}$ & -1.01 & 0.58 & -2.17 & 0.15 & 0.09 \\
\hline Constant & 1.06 & 1.65 & -2.22 & 4.34 & 0.52 \\
\hline \multicolumn{6}{|c|}{ Maintaining an Appropriate Distance from Sick Flocks } \\
\hline Experience & -0.02 & 0.02 & -0.07 & 0.02 & 0.27 \\
\hline Literacy & -0.03 & 0.45 & -0.93 & 0.86 & 0.94 \\
\hline Farming System & 0.90 & 0.60 & -0.30 & 2.10 & 0.14 \\
\hline $\begin{array}{c}\text { Number of } \\
\text { Animals }\end{array}$ & -0.01 & 0.05 & -0.11 & 0.09 & 0.87 \\
\hline $\begin{array}{l}\text { Annual Mortality } \\
\qquad(\%)\end{array}$ & -0.08 & 0.05 & -0.17 & 0.01 & 0.10 \\
\hline $\begin{array}{l}\text { Union } \\
\text { Membership }\end{array}$ & 0.17 & 0.62 & -1.07 & 1.41 & 0.78 \\
\hline Constant & 2.56 & 1.71 & -0.84 & 5.96 & 0.14 \\
\hline
\end{tabular}

3.2.1. Washability of Materials, Cleaning the Troughs, and Avoiding Feed and Water Contamination

On 67/92 of farms, most surfaces were built of washable material. Higher mortality rates were associated with increased use of washable materials, where each percentage increase in annual mortality rate was associated with $6.9 \%$ higher odds (95\% CI -0.6 to $15 \%)$ of recording a higher score for this category. Despite this high use of washable materials, only half of farmers (47/85) cleaned the feed and water troughs on a daily basis. Farmers who had higher mortality rates cleaned the feed and water troughs more frequently. The score for this question increased by 0.09 (95\% CI 0.01 to 0.17$)$ for every percentage increase in the mortality rate. In addition, almost half of the farmers (40/90) took appropriate measures to prevent feed or water to be contaminated by manure. More experienced and literate farmers, along with those with higher mortality rates, practiced this measure more than others in a way that the score for this category increased by 0.10 (95\% CI 0.01 to 0.19 ), $0.78(95 \%$ CI 0.04 to 1.59$)$, and 0.04 (95\% CI 0.00 to 0.07$)$ for every percentage increase in annual mortality $(p=0.02)$, each increase in level of literacy $(p=0.04)$, and every year of experience $(p=0.05)$, respectively (Table 5).

\subsubsection{Providing a Clean Place for Animals, and Disinfecting the Navel Cord}

One-third of the farmers (31/89) reported ensuring that they provide a dry and clean place for their animals to rest. However, higher mortality rates were associated with higher odds of such provision (a $9.1 \%$ higher odds (95\% CI 0.2 to $19 \%$ ) of being in a higher score category score for every percent increase in annual mortality rate; $p=0.046$ ).

A majority of the farmers (72/98) believed that the umbilical cord should be untouched and allowed to dry by itself, $7 / 98$ would tie it so that infection could not enter the body, and only 19/98 disinfected the cord. The results of the ordinal logistic regression analysis showed that annual mortality was associated with the score for this category $(p=0.027)$, with a $1 \%$ increase in annual mortality rate being associated with a $12 \%$ higher odds $(95 \%$ CI 1.3 to $24 \%$ ) of being in a higher-score category. Compared to union members, non-union 
members displayed 3.3 times higher odds of being in a higher score category, but the data were also compatible with no effect of union membership ( $95 \%$ CI 0.8 to $14 ; p=0.099$ ).

3.2.3. Isolating Sick Animals, Maintaining the Health of Sheep Dogs, and Slaughtering on Farm

Of the participants, 38/95 reported isolating sick animals, but this was not influenced by demographic variables. Almost all the participants (96/98) reported slaughtering animals on their farms, with the majority using leftovers as dog food (75/98) or leaving them in the environment (9/98). More than half of the farmers (51/98) performed postmortem examinations on animals that died due to disease. Most of the farmers (70/96) did not vaccinate their sheep dogs against rabies or provide them with healthy food (some, for example, used dead animals or the leftovers of slaughtered animals as dog food). None of these practices was shown by the model as being clearly affected by socio-demographic factors, with only experience and dog health recording a $p$-value $<0.1$. A one-year increase in experience was associated with $3.9 \%$ higher odds ( $95 \%$ CI -0.2 to $8.1 \%$ ) of being in a higher score category.

\subsubsection{Controlling the Spread of Pathogens through Body Secretions, Bodyparts, and} Dead Animals

This area covered the practices that prevented the contamination of the environment by material from sick or dead animals. None of the participants reported burying or burning the aborted fetus or fetal membranes. Of the participants, $60 / 98$ believed that disease could not be transmitted via the wool or hair of an animal, with only 4/98 separating the wool or hair of sick animals from that of healthy ones. Of the participants, 16/98 reported drinking raw milk, and almost one-third (30/98) milked a sick animal to avoid mastitis and then poured the milk on the ground, even though almost half of the farmers (46/98) were aware of brucellosis (in Farsi: Tab-e-Malt) transmission through raw milk. Only 16/98 of the participants reported either burying or burning the bodies of dead animals, 8/98 left them in the environment, and 74/98 fed them to their dogs. These behaviors were not influenced by socio-demographic factors.

\subsection{Between Farm Preventive Measures}

This category included fighting against external parasites, preventing birds and rodents from gaining access feed, quarantining purchased or burrowed animals, controlling the spread of pathogens, the appropriate disposal of dead animals, disinfecting the instruments and maintaining a distance from other flocks during disease outbreaks (Tables 4 and 5).

\subsubsection{Preventing the Spread of Pathogens through Vectors and Animals}

The majority of the farmers (68/99) controlled either flies and fleas (by spraying) or mites (by dipping), but only 23 farmers reported actively controlling both flies and mites. Only 14/95 participants reported keeping newly purchased or borrowed animals separate from the rest of the herd, and only 31/84 possessed the infrastructure to prevent birds and rodents accessing feed (e.g., had a barn where feed could be safely stored). These practices were not affected by the demographic factors.

\subsubsection{Disinfecting Instruments Used Mutually and Maintaining a Distance from} Sick Flocks

In this survey, 38/96 of farmers reported borrowing shears for cutting wool or asked for their colleagues' help during this process. All the respondents stated that their animals would receive some wounds during wool cutting, but only 10/96 disinfected between animals, with $3 / 96$ only disinfecting the shear prior to shearing a flock. These practices were not influenced by demographic factors. Even though grazing sheep and goats in shared pastures is typical in Iran, there is no specific protocol for keeping a reasonable distance from other flocks in case of disease outbreaks. Therefore, a one-kilometer distance 
was considered as "reasonable" in this study. The majority of the farmers in this study (58/97), regardless of their socio-demographic categories, kept an acceptable distance from flocks dealing with a disease or during disease outbreaks.

\subsection{Biosecurity Measures Related to Veterinary Services}

These measures included avoiding the routine self-treatment of animals, recording vaccinations or drug administrations, and contacting a veterinarian when disease occurred.

Of the participants, 78/96 owned a notebook to record the vaccinations and sick animal treatments. Only 20/96 kept records for follow-up treatments, with 58/96 keeping records for renewing work permits or taking loans, or mentioning that the veterinarians or technicians filled in the notebooks for their own future reference. Demographic factors did not impact these practices.

Almost half (49/96) of the participants would ask for a veterinarian when some of their animals (i.e., $10 \%$ of the herd or more) were affected by a disease. Almost all the farmers (95/96) reported self-treating sick animals if less than $10 \%$ were affected. The treatments included traditional treatments (such as using medicinal herbs) and "self-prescribed" antibiotics. Since the sale of antibiotics is not restricted in Iran, 56/97 of farmers used non-veterinary-prescribed antibiotics to treat sick animals. The only demographic factor identified by the model as having an association with one of these practices was experience. Increased experience of farmers resulted in an increased likelihood of requesting a veterinarian's help when dealing with a disease (a 0.06 increase in the score for every year of experience ( $95 \%$ CI 0.02 to 0.11$)$ ).

\section{Discussion}

\subsection{Practicing Preventive Measures by Farmers Comes at a Cost}

This study adds to the relevant body of research by describing the perceptions and practices of nomadic and semi-nomadic pastoralists in Northern Iran in regard to biosecurity practices. The results of this survey clearly show that the practice and perception of biosecurity in the sample population are both unsatisfactory. Combined with the data from Jafari-Gh. [11] on the knowledge, attitude and practice of this population of farmers in regard to infectious diseases, it can be concluded that the poor practice and lack of knowledge of biosecurity and infectious diseases among pastoralists are potential contributors to the high prevalence of infectious diseases in sheep and goats in Iran. This conclusion is consistent with the findings of a recent study on Iranian dairy cattle farms that identified inappropriate biosecurity practices as a major cause of mortality and morbidity [17] and those of Hosein Abadi et al. [18], who concluded that high abortion rates on sheep farms in south-east Iran were related to poor biosecurity measures. It should be mentioned that a probable source of bias in this study was the sampling method (snowball sampling) and the limited number of geographical regions studied. However, since the demographic segmentation of our study population resembles that of the country [7], our results are probably generalizable to pastoralists in both the studied regions and other parts of the country.

Additionally, the results of the statistical analysis suggest that farmers' awareness of biosecurity comes at the cost of losing their animals, since the annual mortality rate was the demographic factor that had the most influence on farmers' perceptions and practice of biosecurity measures. It has been suggested, for parasites, that Iranian sheep and goat farmers are likely to take appropriate action only in response to visible clinical signs (and not subclinical losses and morbidities) [10]. Our finding that higher mortality rates were associated with some improvements in biosecurity practices supports this suggestion.

\subsection{Why Biosecurity Measures Are Not Practiced}

Based on the farmers' answers during the interviews (provided as comments in this section), poor farm practice is strongly associated with a lack of understanding of the risks and consequences of not following biosecurity protocols. Farmers who did not practice preventive measures underestimated the importance of those measures and the benefits 
gained from implementing them. Poor practice may also be linked to insufficient resources; i.e., time, money, workforce, and equipment, all of which are lacking on Iranian pastoral farms. Similarly, Brennan et al. [19] reported that a lack of trust in public organizations (e.g., the UK's Department of Environment, Food and Rural Affairs; DEFRA), underestimating the effectiveness of biosecurity measures, and a lack of resources were among the key causes of an inappropriate biosecurity practice among UK dairy farmers.

\subsection{Within Farm Biosecurity Measures}

4.3.1. Surface Washability, Cleaning the Troughs and Avoiding Feed and Water Contamination

Washing feed and water troughs is a simple practice that can have a large impact on animal health and welfare. Renault et al. [20] reported that half and a third of Belgian dairy farmers clean feed and water troughs on a daily basis, respectively. Additionally, Rolesu et al. [21] reported that more than $80 \%$ of Sardinian small ruminant farmers provided clean and healthy (i.e., not containing manure and mud) water for their animals. Our results suggest that $55 \%$ of Iranian pastoralists cleaned feed and water troughs on a daily basis, and $45 \%$ placed a piece of metal pipe or wood horizontally above the troughs to prevent their animals from getting into them. In some flocks, especially those that used shared pastures, it was observed that the animals would rarely have access to clean water, and some would have to drink wastewater. However, most participants demonstrated a good attitude toward providing clean water to the animals:

"The water must be so clean that even you yourself can drink it. What's the difference between them (the animals) and us? They're living beings too!" said farmer No. 6

\subsubsection{Providing a Clean Place for Animals and Disinfecting the Navel Cord of the New-Born}

Providing a clean and dry place for the animals to rest is very important, especially for reducing the incidence of mastitis in lactating ewes and diarrhea in lambs [22,23]. In addition, the odds of the transmission of many species of bacteria to wounded animals increase if hygiene management is not applied. In this study, almost half of the farmers provided such an environment for their animals, even though the farmers kept their animals very close to their own homes:

"My herd live right beneath my own house, so if their place is wet and smells, my family and I cannot live here" said farmer No. 21

Disinfecting the umbilical cord and even clipping it is taken very seriously in developed countries. Vasseur et al. [24] reported that more than $63 \%$ of Canadian dairy farmers $(n=115)$ disinfect the umbilical cord of newborn calves, and $77 \%$ of Belgian, French and Spanish beef and cattle farmers $(n=205)$ clip and disinfect the navel cord immediately after birth [20]. In our study, however, a majority of farmers $(74 \%)$ believed that the umbilical cord should be untouched and allowed to dry by itself because this was the way of nature. Some farmers mentioned a lack of access to newborn lambs (as lambs are born in the pasture) and appropriate disinfectants (an iodine solution or any other type of antiseptic) as the main causes of their malpractice.

"It's very good to disinfect the cord, but we can't do that because we don't keep them in an intensive system. Our lambs are born in the pasture, and there is nobody there to do the disinfection" said farmer No. 19

On the other hand, a few farmers strongly believed that disinfecting the cord would help them grow healthy lambs and that would be worth the effort:

Farmer No. 68: "Disinfecting the navel is one thing that can reduce mortality by half". 
4.3.3. Isolating Sick Animals, Maintaining the Health of the Shepherd Dogs, and Avoiding Slaughtering on Farm

The segregation of sick animals can be considered a major component of on-farm disease prevention programs. In our study, $40 \%$ of the farmers reported keeping sick animals away from the rest of the herd, which is similar to Swedish dairy farmers (35-40\% had a hospital pen; $n=198$ ) [25], but much higher than Canadian dairy cattle farmers, of whom only $27 \%$ separated the lame and sick animals from the main herd $(n=1157)$ [26]. Additionally, it was reported that $40 \%$ of Wisconsin dairy farmers sell sick cows instead of culling them [12]. Therefore, it seems that quarantine measures are not taken seriously worldwide.

Using the body of dead animals as dog food and on-farm slaughtering were both widely practiced. This was mainly due to a lack of knowledge and attitudes toward the risks associated with these behaviors, and a lack of financial capacity to buy healthy food for farm dogs. This is illustrated by the following responses in regard to feeding dogs:

Farmer No. 1: "If it's a serious disease, like the one with the tumors [probably referring to caseous lymphadenitis], I bury the body. But if it's other kinds of disease, like mouth foaming etc. I open the dead [post-mortem examination] and give it to my dogs."

No. 42: "We use it (the dead body) as dogs' feed if we had already vaccinated them."

And the following highlighting attitudes to on-farm slaughter:

No. 63: "If the animal is badly diseased and is dying, I slaughter it and give it to the shepherd to consume it."

No 55: "I slaughter sick animals and use the meat. But if it's dealing with Siah Zakhm [anthrax] or something dangerous I give the body to the dogs. They can eat everything."

No. 36: “We give it (a sick animal) some medicine. If it doesn't get well we either slaughter it or sell it."

4.3.4. Preventing the Spread of Pathogens through Body Secretions, Bodyparts, and Dead Animals

Pathogens can be transmitted within and between farms via wool, milk, blood, placenta, aborted fetuses, and the dead bodies of diseased animals. Regrettably, our results show that almost none of the participants controlled the spread of pathogens via the appropriate disposal of milk, wool, and placenta or aborted fetuses of sick animals. In fact, only one respondent was effectively controlling the spread of pathogens via these routes. In addition, a majority of the farmers did not have an established plan for the proper disposal of dead bodies.

Although disappointing, the lack of good biosecurity in this area is not limited to sheep and goat farmers residing in low-income countries. A study of Swedish farmers shows that Swedish sheep farmers have the worst practices regarding dead body disposal among Swedish sow, cattle, beef, and sheep farmers [14]. Furthermore, while the disposal of dead bodies was performed effectively on 2/3 of large Wisconsin farms (>200 lactating cows), only $16 \%$ and $24 \%$ of very small and small farms had a system in place for the disposal of dead bodies [12]. Additionally, Damiaans et al. [27] reported that storing dead bodies (before disposal) away from the flock was not a top biosecurity priority for Belgian dairy cattle farmers; Renault et al. [20] reported that only approximately half of Belgian beef and dairy farmers covered dead bodies in a way that prevented access by carnivores, and only $5 \%$ of farmers appropriately disposed of the cadavers. These researchers reported a lack of resources and inappropriate attitudes as the main reasons why these preventive measures were not implemented. By contrast, only a small proportion of Canadian dairy farmers ( $<5 \%$ of participants) used dead cattle as feed for carnivores (domesticated or wild) or left the body in the environment [26], while more than $90 \%$ asked a licensed professional (dead-stock collector) to collect and appropriately dispose of the cadavers. 
In our study, none of the participants reported burying or burning aborted fetuses or placenta, and the majority of respondents believed that disease cannot be transmitted via wool or hair. In addition, eight farmers reported drinking raw milk or eating uncooked liver of slaughtered animals. Sharifi et al. [28] described how drinking raw milk and consuming uncooked liver were among Iranian ranchers' inappropriate habits. The below comments shed light on the attitudes and practices of our interviewees about raw milk consumption:

No. 89: "Warm fresh milk can make you sick, but we let it cool down and pass it through a piece of cloth to make it clean and then drink it."

No. 23: "We don't drink the milk of sheep because it smells, but nothing happens if you drink the raw milk. I do eat raw liver sometimes."

Making a local food called "Gordeh Mast" using raw milk was a common and favorite practice among many farmers (52/98), even though almost half of the farmers (47\%) were aware of brucellosis (in Farsi: Tab-e-Malt) transmission through raw milk. Hoe and Ruegg [12] reported that about $40 \%$ of their sample population would never consume raw milk or its products. However, the same number of farmers reported that people associated with the farm (the employees) consumed such products on a regular basis, and 5\% stated that even people outside the farm routinely used raw milk or raw milk products. Another U.S study reported that approximately two thirds of dairy farmers in eastern South Dakota and western Minnesota consumed raw milk. Further investigation revealed that pathogens were isolated from the bulk tank milk of more than $26 \%$ of the farmers who reported consuming raw milk [29].

\subsection{Between Farm Preventive Measures}

\subsubsection{Preventing the Spread of Pathogens through Vectors and Other Animals}

Rodents can act as vectors for such lethal diseases as leptospirosis, salmonellosis, and FMD [30,31], and birds can transmit a variety of Salmonella spp. [32]. However, many farms have no established plans to fight against these vectors or limit their access to the feed [20,30,33], and this is intensified in sheep farms [33]. In our study, less than onethird of farmers owned the necessary infrastructure to prevent feed access. This lack of infrastructure was principally due to financial concerns, with farmers not believing they would receive a good return on investment in this area. This might have been related to the lack of knowledge and attitudes toward infectious diseases and the way these diseases can be transmitted [11]. Additionally, purchasing rams from neighboring flocks was widely practiced in the study population as a means of reducing inbreeding. Quarantining newly purchased animals is an effective tool to reduce the risk of transmitting diseases between farms [34], and inappropriate quarantine measures are a main cause of disease transmission in Iranian sheep and goat industry [35]. In the current study, the majority of farmers did not quarantine animals following arrival, and very few farmers stated that they performed any kind of diagnostic testing or evaluated the general health of the animal. Animals were only separated if they looked unwell on arrival. The following quote from the interviews reflect this practice:

Farmer No. 50 declared: "I buy rams every couple of years to mix a new blood with the herd, but I don't keep it in a separate place. He goes into the flock from day one."

Other studies in developed countries have also shown that quarantine practices are often inappropriate. For example, Nöremark et al., [14] reported that 50\% Swedish livestock farmers did not quarantine animals upon arrival, while Hoe and Ruegg [12] reported that $51 \%$ of Wisconsin dairy farmers perform no diagnostic tests when purchasing new animals, and Davison et al. [36] concluded that less than one-tenth of English and Welsh dairy farmers performed post-movement diagnostic checks.

Insects, mites, and fleas can also act as vectors of infectious and zoonotic diseases (e.g., Crimean-Congo hemorrhagic fever (CCHF) or anthrax) $[37,38]$. Our results suggest inappropriate practices when it comes to fighting against these vectors, as only one out 
of four farmers had a systemic plan to eradicate flies, fleas, and mites. This might be the reason for the high occurrence of such diseases as CCHF in Iran compared to some of its neighboring countries $[39,40]$. This poor practice might be related to a lack of knowledge in regard to the importance of arthropod vectors and a poor attitude towards the control of these vectors:

"We have a lot of these fleas here and they bother us a lot. But we don't spray anything, they disappear themselves after a while." said No. 27

"We have some chickens and they eat the mites and flies. We do nothing for that." said farmer No. 32

The results of surveys conducted in other countries demonstrate a lack of best practice in these areas as well. For example, Rolesu et al. [21] reported that less than half of Sardinian farmers use any kind of trap to control insects, and a study in Belgium showed that insect control was amongst the least practiced preventive measures on dairy cattle farms (ranked 16 out of 20, where 20 was lowest priority) [27].

4.4.2. Disinfecting Shared Instruments, and Maintaining a Distance from Flocks during Outbreaks

Borrowing tools from peers is a common practice among farmers across the world [26,41,42]. However, tools that have been contaminated by blood, mucus, or feces are an important source of disease transmission among and between farms [43]; hence, it is very important to clean and disinfect borrowed tools before using them [43,44]. Our results demonstrate that $40 \%$ of the farmers we interviewed borrowed scissors for cutting wool or asked for other farmers' help during this process. Nevertheless, even though all the farmers reported that the shearing process left wounds on some animals, almost none of them disinfected the scissors before each cut.

Grazing sheep and goats in shared pastures is typical of the Iranian small ruminant industry and is one of the key reasons for the rapid spread of infectious diseases between holdings. The majority of farmers in this study $(60 \%)$ did appreciate these risks and would keep their animals at least one kilometer away from flocks with disease outbreaks. Nevertheless, there was a significant variation in knowledge levels and, thus, in approach, between the respondents. For example:

No. 49: "If I know that another herd somewhere is suffering from a disease, I won't even get close to that region. I've heard disease can transfer even through my shoes."

By contrast, another respondent stated:

"I try to prevent them from being mixed with each other (his own herd and the sick one), but if they do, I vaccinate my animals" said No. 51

\subsection{Biosecurity Practices Related to Veterinary Services}

During the interviews, the majority of farmers stated that they usually self-treated sick animals or those who look to be sick either using traditional medicines or self-prescribed antibiotics, with almost half of them reporting using veterinarians to use to treat sick animals. Similarly, Brennan and Christley [41] reported that only $36 \%$ of English farmers had scheduled veterinary visits, and DEFRA [45] reported that two-third of British beef farmers contacted veterinarians only in case of an emergency. For our respondents, the lack of veterinary involvement may reflect financial constraints but may also be at least partly due to a lack of trust of veterinary or public organizations.

Keeping track of administered treatments and vaccinations is necessary for farmers to manage the health of flocks, assess the success of treatments, and discern emerging diseases [46]. However, to be useful, these records need to be used. Although almost $80 \%$ of the participants in this study owned a notebook for recording treatments, only $21 \% \mathrm{kept}$ the notebook to help them manage flock health. 


\section{Conclusions}

This study sheds light on the behavior and practice of sheep and goat farmers regarding biosecurity in two key provinces of Iran, Alborz and Qazvin, where access to technology and veterinary services is higher compared to many parts of the country. A wide range of practices was observed during this survey. Some farmers seemed to consider many aspects of biosecurity protocols, and some followed no preventive measures. The results of the regression analysis suggested that annual mortality rate was the one demographic factor that influenced farmers' perception and practice of biosecurity measures most. This magnifies the need for conducting educational interventions to improve farmers' knowledge about biosecurity measures, and implementing programs to alter farmers' perspective in regard to the effectiveness of preventing measures in reducing mortality and improving productivity on farms.

Author Contributions: Conceptualization, A.J.-G. and Z.H.; methodology, R.A.L., A.J.-G. and Z.H.; Analysis, R.A.L. and N.E.; investigation, A.J.-G., Z.H., P.S., S.J.-G., M.M.-L., J.Y. and M.S.; writingoriginal draft preparation, A.J.-G. and S.J.-G.; writing-review and editing, R.A.L. and A.J.-G.; supervision, R.A.L., N.E. and J.Y.; project administration, A.J.-G. All authors have read and agreed to the published version of the manuscript.

Funding: This research received no external funding.

Institutional Review Board Statement: Not applicable.

Informed Consent Statement: As it was impossible to ask mostly illiterate farmers to sign a written consent form, informed consent was taken verbally from each participant at the beginning of each interview.

Data Availability Statement: The data available in this study are available based upon request from the corresponding author.

Acknowledgments: The authors would like to express their gratitude and appreciation to all the farmers who kindly participated in this study and patiently answered our questions. The authors would also like to thank Farhang Sasani, Reza Asadimoghadam, and Ahmad Jafari Ghavamabad for their guidance throughout the study. This research did not receive any specific grant from funding agencies in the public, commercial, or not-for-profit sectors.

Conflicts of Interest: The authors declare no conflict of interest.

\section{References}

1. Rushton, J.; Gilbert, W. The Economics of Animal Health: Direct and Indirect Costs of Animal Disease Outbreaks. 84th OIE World Assembly. 2016. Available online: https://www.oie.int/fileadmin/Home/eng/Publications_\%26_Documentation/docs/pdf/ TT/2016_A_84SG_9.pdf (accessed on 4 August 2021).

2. Bazarghani, T.T.; Charkhkar, S.; Doroudi, J.; Hassan, E.B. A Review on Peste des Petits Ruminants (PPR) with Special Reference to PPR in Iran. J. Vet. Med. Ser. B 2006, 53, 17-18. [CrossRef]

3. Abdollahi, D.; Rashtibaf, M. FMD Situation in Iran, 2014. Global Framework for the Progressive Control of Transboundary Animal Diseases. 2015. Available online: https:/ /www.fao.org/fileadmin/user_upload/eufmd/Roadmap_2015/Iran.pdf (accessed on 20 August 2021).

4. Mirzaie, K.; Barani, S.; Bokaie, S. A review of sheep pox and goat pox: Perspective of their control and eradication in Iran. J. Adv. Vet. Anim. Res. 2015, 2, 373-381. [CrossRef]

5. Craddock, F.; Dement, A. Biosecurity for Sheep and Goat Producers. Texas FARMER Collection. 2008. Available online: https: / / oaktrust.library.tamu.edu/bitstream/handle/1969.1/87555/pdf_2605.pdf?sequence=1 (accessed on 4 August 2021).

6. Valizadeh, R. Iranian Sheep and Goat Industry at a Glance. In Stress Management in Small Ruminant Production and Product Processing 2010. Available online: https:/ / profdoc.um.ac.ir/articles/a/1013463.pdf (accessed on 4 August 2021).

7. SCI. Iran Statistical Yearbook. Statistical Centre of Iran Tehran, Iran. 2012. Available online: https://www.amar.org.ir/Portals/1/ yearbook/1390/4.pdf (accessed on 20 August 2021).

8. Pezeshki-Raad, G.; Aghai, H. An Assessment of Contact Farmers' Educational Activities in Iran (A national study). In Proceedings of the 18th AIAEE Annual Conference, Durban, South Africa, 1-4 May 2002. Available online: https://www.aiaee.org/ attachments/article/1284/pezeshki-raad360-366.pdf (accessed on 4 August 2021).

9. Soltani, S.; Ahmadpour, A.; Feali, S. Factors Influencing rural women participation in agricultural extension programs, case study Mazandaran, Iran. Int. J. Agric. Sci. Res. 2011, 2, 17-24. 
10. Sazmand, A.; Alipoor, G.; Zafari, S.; Zolhavarieh, S.M.; Alanazi, A.D.; Sargison, N.D. Assessment of knowledge, attitudes and practices relating to parasitic diseases and anthelmintic resistance among livestock farmers in Hamedan, Iran. Front. Vet. Sci. 2020, 7. [CrossRef] [PubMed]

11. Jafari-Gh, A.; Laven, R.; Eila, N.; Yadi, J.; Hatami, Z.; Soleimani, P.; Lesko, M.M.; Sinafar, M.; Heidari, E. Transboundary and infectious diseases of small ruminants: Knowledge, attitude, and practice of nomadic and semi-nomadic pastoralists in northern Iran. Small Rumin. Res. 2019, 183, 106039. [CrossRef]

12. Hoe, F.; Ruegg, P. Opinions and Practices of Wisconsin Dairy Producers About Biosecurity and Animal Well-Being. J. Dairy Sci. 2006, 89, 2297-2308. [CrossRef]

13. Kuster, K.; Cousin, M.E.; Jemmi, T.; Schüpbach-Regula, G.; Magouras, I. Expert opinion on the perceived effectiveness and importance of on-farm biosecurity measures for cattle and swine farms in Switzerland. PLOS ONE 2015, 10, e0144533.

14. Nöremark, M.; Frössling, J.; Lewerin, S.S. Application of Routines that Contribute to On-farm Biosecurity as Reported by Swedish Livestock Farmers. Transbound. Emerg. Dis. 2010, 57, 225-236. [CrossRef]

15. Kamalzadeh, A.; Rajabbaigy, M.; Kiasat, A. Livestock production systems and trends in livestock industry in Iran. J. Agric. Soc. Sci. 2008, 4, 183-188.

16. Goodman, L.A. Snowball sampling. Ann. Math. Stat. 1961, 32, 148-170. [CrossRef]

17. Ilbeigi, K.; Bokaie, S.; Aghasharif, S.; Magalhaes, R.S.; Rashtibaf, M. Risk factors for recurrence of FMD outbreaks in Iran: A case-control study in a highly endemic area. BMC Vet. Res. 2018, 14, 253. [CrossRef]

18. Hosein, A.E.; Saadati, D.; Najimi, M.; Hassanpour, M. A study on Mycoplasma agalactiae and Chlamydophila abortus in aborted ovine fetuses in Sistan and Baluchestan region, Iran. Arch. Razi Inst. 2019, 74, 295-301.

19. Brennan, M.L.; Wright, N.; Wapenaar, W.; Jarratt, S.; Hobson-West, P.; Richens, I.F.; Kaler, J.; Buchanan, H.; Huxley, J.N.; O'Connor H.M. Exploring Attitudes and Beliefs towards Implementing Cattle Disease Prevention and Control Measures: A Qualitative Study with Dairy Farmers in Great Britain. Animals 2016, 6, 61. [CrossRef] [PubMed]

20. Renault, V.; Humblet, M.F.; Moons, V.; Bosquet, G.; Gauthier, B.; Cebrián, L.M.; Casal, J.; Saegerman, C. Rural veterinarian's perception and practices in terms of biosecurity across three European countries. Transbound. Emerg. Dis. 2018, 65, e183-e193. [CrossRef]

21. Rolesu, S.; Loi, F.; Cappai, S.; Coccollone, A.; Cataldi, M.; Usala, P.; Podda, A.; Deliperi, S.; Oppia, P.; Natale, A.; et al. Description and typology of dairy sheep farm management profiles in Sardinia. Small Rumin. Res. 2018, 164, 39-47. [CrossRef]

22. Delafosse, A.; Castro-Hermida, J.A.; Baudry, C.; Ares-Mazás, E.; Chartier, C. Herd-level risk factors for Cryptosporidium infection in dairy-goat kids in western France. Prev. Vet. Med. 2006, 77, 109-121. [CrossRef]

23. Mørk, T.; Waage, S.; Tollersrud, T.; Kvitle, B.; Sviland, S. Clinical mastitis in ewes; bacteriology, epidemiology and clinical features. Acta Vet. Scand. 2007, 49, 23. [CrossRef]

24. Vasseur, E.; Borderas, F.; Cue, R.I.; Lefebvre, D.; Pellerin, D.; Rushen, J.; Wade, K.M.; De Passillé, A.M. A survey of dairy calf management practices in Canada that affect animal welfare. J. Dairy Sci. 2010, 93, 1307-1316. [CrossRef] [PubMed]

25. Emanuelson, U.; Sjöström, K.; Fall, N. Biosecurity and animal disease management in organic and conventional Swedish dairy herds: A questionnaire study. Acta Vet. Scand. 2018, 60, 23. [CrossRef]

26. Denis-Robichaud, J.; Kelton, D.; Bauman, C.; Barkema, H.; Keefe, G.; Dubuc, J. Biosecurity and herd health management practices on Canadian dairy farms. J. Dairy Sci. 2019, 102, 9536-9547. [CrossRef]

27. Damiaans, B.; Sarrazin, S.; Heremans, E.; Dewulf, J. Perception, motivators and obstacles of biosecurity in cattle production. Vlaams Diergeneeskd. Tijdschr. 2018, 87, 150-163. [CrossRef]

28. Sharifi, M.B.; Metanat, M.; Mardani, M. Poor Dietary and behavior patterns: Related risk factors to Brucellosis in Sistan and Baluchestan. Iranian J. Infect. Dis. 2007, 12, 59-62.

29. Jayarao, B.M.; Henning, D.R. Prevalence of foodborne pathogens in bulk tank milk. J. Dairy Sci. 2001, 84, 2157-2162. [CrossRef]

30. Endepols, S.; Klemann, N.; Pelz, H.J.; Ziebell, K.L. A scheme for the placement of rodenticide baits for rat eradication on confinement livestock farms. Prev. Vet. Med. 2003, 58, 115-123. [CrossRef]

31. Sarrazin, S.; Cay, A.B.; Laureyns, J.; Dewulf, J. A survey on biosecurity and management practices in selected Belgian cattle farms. Prev. Vet. Med. 2014, 117, 129-139. [CrossRef]

32. Hughes, L.A.; Shopland, S.; Wigley, P.; Bradon, H.; Leatherbarrow, A.H.; Williams, N.J.; Bennett, M.; De Pinna, E.; Lawson, B.; Cunningham, A.A.; et al. Characterisation of Salmonella enterica serotype Typhimurium isolates from wild birds in northern England from 2005-2006. BMC Vet. Res. 2008, 4, 4. [CrossRef] [PubMed]

33. Sahlström, L.; Virtanen, T.; Kyyrö, J.; Lyytikäinen, T. Biosecurity on Finnish cattle, pig and sheep farms-results from a questionnaire. Prev. Vet. Med. 2014, 117, 59-67. [CrossRef]

34. Talafha, A.Q.; Hirche, S.M.; Ababneh, M.M.; Al-Majali, A.M. Prevalence and risk factors associated with bovine viral diarrhea virus infection in dairy herds in Jordan. Trop. Anim. Health Prod. 2009, 41, 499-506. [CrossRef] [PubMed]

35. Esmaeili, H. Brucellosis in Islamic republic of Iran. J. Med. Bacteriol. 2014, 3, 47-57.

36. Davison, H.C.; Smith, R.P.; Sayers, A.R.; Evans, S.J. Dairy farm characteristics, including biosecurity, obtained during a cohort study in England and Wales. Cattle Pract. 2003, 11, 299-310.

37. Turell, M.J.; Knudson, G.B. Mechanical transmission of Bacillus anthracis by stable flies (Stomoxys calcitrans) and mosquitoes (Aedes aegypti and Aedes taeniorhynchus). Infect. Immun. 1987, 55, 1859-1861. [CrossRef] 
38. Gargili, A.; Estrada-Peña, A.; Spengler, J.R.; Lukashev, A.; Nuttall, P.A.; Bente, D.A. The role of ticks in the maintenance and transmission of Crimean-Congo hemorrhagic fever virus: A review of published field and laboratory studies. Antivir. Res. 2017, 144, 93-119. [CrossRef]

39. Keshtkar-Jahromi, M.; Sajadi, M.M.; Ansari, H.; Mardani, M.; Holakouie-Naieni, K. Crimean-Congo hemorrhagic fever in Iran. Antivir. Res. 2013, 100, 20-28. [CrossRef] [PubMed]

40. Hosseini, Z.; Salehi, V.M.; Ahmadnia, S.; Fakoorziba, M.R.; Jalali, T.; Telmadarraiy, Z.; Moemenbellah-Fard, M.D. Hard ticks infesting domestic ruminants, species composition and infection with Crimean-Congo hemorrhagic fever virus in a highland province, SW Iran. J. Health Sci. Surveill. Syst. 2019, 7, 52-59.

41. Brennan, M.L.; Christley, R.M. Biosecurity on cattle farms: A study in north-west England. PLoS ONE 2012, 7, e28139. [CrossRef] [PubMed]

42. Sarrazin, S.; Damiaans, B.; Renault, V.; Saegerman, C. Transmission of cattle diseases and biosecurity in cattle farms. Biosecurity Anim. Prod. Vet. Med. Princ. Pract. 2019, 357-408. [CrossRef]

43. Caldow, G.L.; Crawshaw, M.; Gunn, G.J. Herd health security in the suckler herd. Cattle Pract. 1998, 6, 175-179.

44. DEFRA Archive Website. Better Biosecurity Provides Peace for Mind, Healthy Stock and a More Viable Business. 2002. Available online: http:/ / vetpath.co.uk/cvs/bio_poultrykeep.pdf (accessed on 4 August 2021).

45. DEFRA. Animal Health, The Report of the Chief Veterinary Officer. 2007. Available online: http://www.bovinetb.info/docs/ cvo_reports/2007report.pdf (accessed on 4 August 2021).

46. Pritchard, G.C. Added animals: The challenge to preventive medicine. Cattle Pract. 1996, 4, 253-255. 